\title{
The Ownership Choice of Leveraged Buyout Company
}

\author{
Jaisik Gong $^{1^{*}}$ and Choong-hwan Kim ${ }^{2}$ \\ ${ }^{1}$ Professor, Dept. of Insurance \& Finance, Daegu University, \\ ${ }^{2}$ Professor, Dept. of Industrial Information, Kongju Nat'l University \\ 차입 인수합병기업의 소유구조 선택

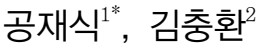 \\ ${ }^{1}$ 대구대학교 금융보험학과, ${ }^{2}$ 공주대학교 산업정보학과
}

\begin{abstract}
Leveraged buyouts (LBO) means the acquisition of a company using bonds and loans. There are the prolific volumes of LBO transactions in the international M\&A markets, and its influence to the financial market is increasingly huge. However, there are very few LBO transaction in the domestic M\&A market and there are also few researches in this field due to the private nature of LBO transactions. Once a company is privatized through a LBO transaction, it is not so long before it is relisted on the stock exchange or it is resold to a third-party investor. In order to repay the borrowed money, an LBO investor may decide to end a company's private status through an exit via an initial public offering (IPO) or a takeover. In this paper, we expand Kaplan's study on the organizational status of post leveraged buyout (LBO) transaction. We find that there is a significant change starting 1986. Most notably, fewer LBOs remain private, the median holding period of the LBO was cut in half to 3.2 years and of those that exit, IPO exits had significantly shorter holding periods. Regression analysis shows that good market conditions lengthen the holding period of a LBO investment whereas the size of the transaction shortens it.
\end{abstract}

요 약 인수합병(LBO)을 실행한 기업중 외부차입이 큰 경우에는, 일정기간 후에 인수비용을 충당하기 위해 차입한 막대한 자금을 상환하기 위해 일반 기업공모나 제 3 자 기업매각을 시도할 수 있다. 일반 기업공모는 소유지분 공개를 통한 공기업으로의 전환이고, 제 3 자 기업매각은 소유구조상 사기업 형태의 지속을 의미한다. 따라서 외부차입에 의한 인수합병 기업의 소유구조 선택은 최초공모주(IPO) 발행을 통한 공기업으로의 전환인가 또는 제 3 자 기업매각을 통한 사기업 형태의 유지인가에 대한 의사결정의 문제이다. 국내에서는 외부차입에 의한 인수합병(LBO) 사례가 매우 적 다. 그러나 해외에서는 외부차입에 의한 인수합병(LBO) 거래가 폭발적으로 증가하여 오고 있고, 이러한 거래가 금융 시장에 미치는 영향 또한 지대하다. 본 연구는 미국의 기업자료를 대상으로 기업의 경영자가 외부차입을 통한 인수 합병을 실행한 기업의 소유구조 선택에 어떠한 요인들이 영향을 미치는가를 분석하였다. 연구결과, 인수합병의 규모, 호황 불황 등 시장 상황 등이 차입을 통해 인수합병을 실행한 LBO 기업이 계속 사기업 형태로 유지할지 또는 기업 공개를 시도하여 공기업으로 전환할지 하는 소유구조의 선택 의사결정에 중대한 영향을 미치는 것으로 나타났다.

Key Words : Leveraged Buyouts; M\&A; IPO

\section{Introduction and Prior Literature}

A leveraged buyout (LBO) means the acquisition of another company using a significant amount of borrowed money to meet the cost of acquisition. There are the prolific volumes of LBO transactions in the international M\&A markets, and its influence to the financial market is increasingly huge. However, there are very few LBO

\footnotetext{
This research was supported by the Daegu University Research Grant, 2008.

*Corressponding Author : Jaisik Gong (jaigong@hanmail.net)

Received January 17, $2011 \quad$ Revised February 14, $2011 \quad$ Accepted March 10, 2011
} 
transaction in the domestic M\&A market and there are also few researches in this field due to the private nature of LBO transactions. Only recently, Hyundai Group is reported to attempt to take over Hyundai Engineering \& Construction in a way of leveraged buyout (LBO) transaction with a French bank. Hardly, any LBO transactions disclose the terms or even the size of the deal to the general public and hence there is little to none data available. This is eminently shown from the Social Sciences Research Network as only 63 abstracts contain the word "LBO" out of the 147,870 research papers listed (as of April 13, 2007).

Kaplan [1] conducted a study on the organizational status of 183 LBOs between 1979 and 1986 where he showed that $62 \%$ of them were still privately owned, $14 \%$ are now independent companies and $24 \%$ are owned by other public companies. Kaplan's study on the organizational status of 183 LBOs between 1979 and 1986 showed that the median holding period for these transactions was 6.82 years, and reasons from this that LBOs were neither short lived nor permanent but are transitory organizational forms. Kaplan agrees with Rappaport's [2] view that they are transitory organizational forms.

Brau, Francis, and Kohers [3] tested whether the private company would exit via an IPO or acquisition, using a sample of 9,500 private US companies. Brau, Francis, and Kohers [3] has showed that companies belonging to a hitech industry and to an industry with high concentration, current cost of debt, percent of inside ownership in the firm, size of the firm, and the "hotness" of the IPO market improve the chances of a private company to go public. Chemmanur and Fulghieri [4] addressed when a firm go public rather than undertake its projects using private equity financing. They posited that the equilibrium timing of the going public decision is determined by the firm's trade off between placing shares privately with a risk averse venture capitalist and selling shares in an IPO to numerous small investors. Boot, Gopalan, and Thakor [5] also analyzed an entrepreneur's choice between private and public ownership in the theoretical framework.

Pagano, Panetta, and Zingales [6] have studied a large sample of Italian companies to find out why some companies decide to go public while others do not. They found that the most obvious benefit of going public is to gain access to an alternative to bank finance and reduce the cost of capital. So companies with large investment plans and high levels of debt or leverage are likely to go public. Going public may also give the company more bargaining power relative to its bankers and reduce its interest costs on existing debt. Pagano and Roell [7] compared to different strategies of going public and selling shares privately. They argue that going public is more costly but can lead to more dispersion of share holders and therefore the controlling shareholder can avoid excessive monitoring from other shareholders.

\section{Data and Descriptive Statistics}

Information regarding LBO transactions is extremely private. Private equity firms are hesitant in emitting not only the terms of the deal, but also the exact dollar amount of the deal to the general public due to the exclusiveness of their business. Public relations departments of some private equity shops would not even provide us with the names of the companies they purchased through LBOs. we had no choice but to collect the data I needed manually.

We decided to use the reverse process, in other words, start from certain information. In one way or another, private equity firms have to raise debt from the capital market to finance their LBOs and they must provide debt investors with some information. There were more detailed information regarding the debt data of the LBO transaction such as trances, rates and covenants but we did not need this information. Adding an additional 11 private equity firms that we were familiar with, our search under the 21 private equity firms provided us with debt data on more than 500 LBO transactions. There were certain cases where the private equity firms raised debt on two different dates for the same transaction, in which we added the two observations and used the earlier date for regression purposes. Because of the exclusiveness of these transactions, there was certain information that even VentureXpert did not have - most of them being the exact size of the transaction and the date and value of the exit. From the 500 or more debt data points, there were only 200 data points that contained some or all the 
The Ownership Choice of Leveraged Buyout Company

[Table 1] Number of LBO Deals and Exits by Year

\begin{tabular}{|c|c|c|c|c|c|c|}
\hline & Initiated date & Exit Date $^{*}$ & Market Condition $^{* *}$ & 30-year T Bill Rate & IPO & Acq. \\
\hline 1986 & 2 & 0 & Bull & 7.48 & 0 & 0 \\
\hline 1987 & 3 & 0 & Bear & 8.42 & 0 & 0 \\
\hline 1988 & 5 & 1 & Bear & 8.84 & 0 & 0 \\
\hline 1989 & 3 & 2 & Bull & 8.46 & 1 & 0 \\
\hline 1990 & 4 & 3 & Bear & 8.21 & 2 & 0 \\
\hline 1991 & 0 & 3 & Bull & 7.77 & 3 & 0 \\
\hline 1992 & 2 & 2 & Bear & 7.21 & 3 & 0 \\
\hline 1993 & 4 & 2 & Bear & 6.22 & 2 & 0 \\
\hline 1994 & 8 & 2 & Bear & 7.69 & 2 & 0 \\
\hline 1995 & 10 & 2 & Bull & 6.02 & 1 & 0 \\
\hline 1996 & 10 & 7 & Bull & 6.80 & 1 & 1 \\
\hline 1997 & 22 & 2 & Bull & 5.80 & 6 & 1 \\
\hline 1998 & 21 & 5 & Bull & 5.09 & 0 & 2 \\
\hline 1999 & 22 & 7 & Bull & 6.49 & 4 & 1 \\
\hline 2000 & 10 & 4 & Bear & 5.54 & 6 & 1 \\
\hline 2001 & 5 & 8 & Bear & 5.43 & 2 & 1 \\
\hline 2002 & 8 & 7 & Bear & 4.85 & 3 & 5 \\
\hline 2003 & 15 & 15 & Bull & 4.97 & 1 & 6 \\
\hline 2004 & 16 & 19 & Bear & 4.59 & 5 & 9 \\
\hline 2005 & 17 & 19 & Bear & 4.68 & 5 & 13 \\
\hline 2006 & 13 & 0 & Bull & 4.93 & 13 & 6 \\
\hline Total & 200 & $110^{*}$ & & & 60 & 46 \\
\hline
\end{tabular}

Average Holding Period 3.7 Years; Median Holding Period 3.2 Years

*There are some LBOs still on hold and some exit dates that are missing

${ }^{* *}$ Depending on whether the S\&P 500 returned more than the 20 year historical average of $9.3 \%$

information we needed. Of the resulting 200 historical LBO transactions, $30.5 \%$ went public, $23.5 \%$ were sold to other public or private companies, $2.5 \%$ faced bankruptcy and $43.5 \%$ were still held by the private equity firms as shown in Table 1 . There were 21 known private equity firms represented in our sample but we could not identify the sponsoring private equity firm for 10 observations. Out of the ones that we could identify, $61.5 \%$ were the "powerful" private equity firms according to Fortune 500.

We categorized the industry of the LBO companies using the Fama French Five Industry categorization which consists of consumer industry, manufacturing industry, hi tech industry, health industry and others. As a result, $24 \%$ belonged to the consumer industry and manufacturing industry, $11 \%$ belonged to the hi tech industry, $18 \%$ belonged to the health industry and the remaining $25 \%$ were other. Then we arranged the deals by the years they were initiated and exited. There is a gap between the number of deals initiated and exited number of deals because 87 of the initiated transactions are still being held by the private equity firms and there was no information available on the date of the exit of three LBO transactions, although it was known that it went through an IPO or acquisition. Many of the LBO transactions were initiated in the mid $1990 \mathrm{~s}$ and started to exit around the early 2000s. The median holding period from initiation to exit was 3.18 years. IPO exits were steadier across the time whereas acquisition exits picked off around 2001. Additionally, LBO companies that exited via an IPO had a median holding period of 2.28 years whereas the LBO companies that exited via an acquisition had a median holding period of 4.80 years. A possible explanation why IPO holding periods are shorter is that an IPO is a self serving process where the private equity firm had total control over the pace. Acquisitions, on the other hand, require seeking and negotiating with potential buyers over an extended period of time.

We also measured market condition at that time using the Standard \& Poor 500 Index. We categorized the market condition as "Bull" whenever the index returned more than its 20 year historical average of $9.3 \%$ and "Bear" else wise. To obtain a measure for the cost of debt 
at that time period, we used the 30 year U.S. Treasury Bill rate obtained from Yahoo! Finance.

\section{Testing Model and Results}

In our paper, it would be naturally interesting to find what affects a LBO created private company's decision of exiting through an IPO or acquisition. Our initial conjecture was that for LBO transactions, the reputation of the private equity firm and the leverage of the transaction would also affect the IPO/Acquisition decision for LBO created private companies. Considering that all private equity firms' first goal is to sell the company to the other buyer than conducting an IPO, more "powerful" private equity firms might be able to find and negotiate with potential buyers more easily than the other "not so

powerful" firms, thus lower probability of an IPO. For leverage, if the leverage of the LBO transaction were to be relatively high and the target company has a handful of debt in its balance sheet, IPO would be a good way to diversify its capital structure with equity and hence increase in the private company's probability of an IPO.

LBOs take advantage of the tax shield of debt and the "shock therapy" of the private equity firm, and exit when there is return to be made. From the data we collected, we were interested to see if there were any changes in the organizational statuses of LBO after 1986, which is different from the result of Kaplan [1]. For 110 LBO transactions from 1986 to 2006 , we find that $44 \%$ of them are still privately owned, $31 \%$ conducted IPOs and became public, $24 \%$ were sold to other private or public companies and 3\% faced bankruptcy. The median holding period was 3.20 years, more than half of what it was before 1986. The fact that there are less privately held LBO companies than Kaplan's time period is a good indicator of the recent efforts of private equity firms to have a quick turnaround in investments. Within the data, we also found that LBO transactions that exited through an IPO had much shorter holding periods than those that are exited acquisitions where the median holding period of an IPO exited LBO transaction was 2.28 years whereas and acquisition exited LBO transaction was 4.79 years. Our interpretation of this result was that acquisitions require time for seeking and negotiating with potential buyers whereas IPOs are conducted at the private equity firm's own pace.

When the initiation and exits of LBOs were arranged by time, it was eminent that most were initiated and exited during the start of the bull market. A bulk of LBOs were initiated during the booming mid 1990 market and then slowed down around the "dot com bust" of the late 1990s. As the economy picked up in 2003, many new LBOs were initiated and the ones that were held exited Looking at the exits alone, we find that the numbers of IPO exits are relatively stable over time than acquisitions. Considering the industry of the LBO companies and their exits, we find that most companies, except those in the health industry, exit via IPOs. Additionally, a much higher proportion of companies that belong to the manufacturing or hi tech industry are still held or faced bankruptcy than those that belong to another industry.

After observing that the holding period of LBO transactions was nearly cut to half since 1986, we were curious to see what affected the holding period of LBO investments. There was no prior research available for my reference, so we decided to reprocess the data and variables that we used in our prior regression to test any relationships. The independent variables we tested for were firm reputation, market condition, size of the transaction, leverage of the transaction and the industry that the LBO company belonged to. The characteristics of these variables are as the IPO regression shown above, but this time they were test to see whether it affected the holding period that was put in natural log for regression purposes. Our tested model is as follow:

Holding period of IPO $=\beta_{f} \cdot$ Firm reputation

$+\beta_{m} \cdot$ Market condition $+\beta_{s}$ - Size of the transaction

$+\beta_{l} \cdot$ Leverage of the transaction $+\sum \beta_{i} \cdot$ Industry Factors

We initially predicted that firms with a high reputation would have a better negotiating/processing power and a better market condition would aid the cause of an IPO or sell through acquisition; thus both would shorten the holding period. Firm reputation, market condition and industry factors are estimated as dummy proxy variables. The size and the leverage of the transaction on the other 
[Table 2] Linear Regression of LBO Continuances

Holding period of IPO $-\beta_{f}$ • Firm reputation $+\beta_{m} \cdot$ Market condition $+\beta_{s}$. Size of the transaction $+\beta_{l} \cdot$ Leverage of the transaction $+\sum \beta_{i} \cdot$ Industry Factors

\begin{tabular}{|c|c|c|c|c|}
\hline Variable & Coefficient & Std. Err & $\mathrm{t}$ Stat & 0.46 \\
\hline FirmRep & 0.12 & 0.74 & 0.16 & 0.03 \\
\hline BullBear & 0.37 & 2.27 & 0.16 & 0.04 \\
\hline Size & 0.14 & 2.13 & 0.07 & 0.59 \\
\hline Leverage & 0.20 & 0.54 & 0.37 & 0.64 \\
\hline Consumer & 0.10 & 0.47 & 0.21 & 0.35 \\
\hline Manfact & 0.21 & 0.93 & 0.22 & 0.53 \\
\hline Hi-Tech & 0.18 & 0.63 & 0.29 & 0.54 \\
\hline Health & 0.14 & 0.61 & 0.23 & 0.00 \\
\hline Intercept & 7.56 & 13.23 & 0.57 & \\
\hline
\end{tabular}

Regression Statistics

\begin{tabular}{|l|r|}
\hline Multiple R & 0.37 \\
\hline R Square & 0.14 \\
\hline Adjusted R Square & 0.07 \\
\hline Standard Error & 0.77 \\
\hline Observations & 110 \\
\hline Significance F & 0.05 \\
\hline
\end{tabular}

\section{Notes:}

1 if Fortune 500 Top Ten

1 if S\&P 500 returned more than historical average

Size $=\mathrm{Ln}$ of the deal in \$millions

Leverage $=$ Debt Raised $/$ Deal Size

1 if belongs to that industry

1 if belongs to that industry

1 if belongs to that industry

1 if belongs to that industry

hand would lengthen the holding period as larger firms will have a harder time arranging the exit transaction (whether it be an IPO or acquisition) and the public or potential acquirer would be hesitant in investing a company that is heavily levered.

Table 2 shows that the resulting regression was significant with where the market conditions lengthened the holding period and the size of the transaction shortening the holding period. These results were opposite of our initial predictions. Since we convince that our model has been correctly specified one with well-measured variables, a low $\mathrm{R}^{2}$ in Table 2 would be of only secondary interest to us as in most finance papers.

\section{Conclusions}

In our paper, we obtained also more interesting results about the holding periods of LBO transactions. We conducted an in depth analysis on our data more than the study of Kaplan [1] on the organizational status and what affected the holding period. For LBO transactions from 1986 to 2006, we find that $44 \%$ of them are still privately owned, $31 \%$ conducted IPOs and became public, $24 \%$ were sold to other private or public companies and $3 \%$ faced bankruptcy. Interestingly, the median holding period was 3.20 years, more than half of what it was before 1986. This is a good indicator of the recent efforts and pressure of private equity firms to exit their investment quickly. Additionally, through regression analysis, we find that holding periods become longer as the market conditions are good and shorter as the size of the LBO transaction becomes smaller.

Our conclusions are summarized as follows. IPO exit of LBOs have longer holding periods $(p=0.001)$. Larger deals have shorter holding periods $(\mathrm{p}=0.02)$. PE Shops of high repute have longer holding periods $(\mathrm{p}=0.10)$. IPOs have shorter holding periods $(p=0.001)$. Leverage or size of the transaction does not affect the holding period of the LBO investment.

Private equity firms play a valuable role in helping transform under-performing companies. While controlling financial stability issues, policies to boost M\&A and private equity markets should be strongly implemented. 


\section{References}

[1] Kaplan, Steven N., "The Staying Power of Leveraged Buyouts", Journal of Financial Economics 29, pp. 287 $-313,1992$.

[2] Rappaport, A., "The Staying Power of the Public Corporation", Harvard Business Review, Vol. 68, pp. 96-104, 1990.

[3] Brau, J., B. Francis, and N. Kohers, "The Choice of IPO versus Takeover: Empirical Evidence", Journal of Business, 76(4), pp. 583-612, 2003.

[4] Chemmanur, Thomas J. and Fulghieri, P., "A Theory of the Going-Public Decision", The Review of Financial Studies 12, pp. 249-279, 1999.

[5] Boot, A.W.A., Gopalan, R., Thakor, A., "The Entrepreneur's Choice between Private and Public Ownership", Journal of Finance, 61(2), pp.803-836, 2006.

[6] Pagano, M., Panetta, F. and Zingales, L., "Why do companies go public? An empirical analysis", Journal of Finance 53, pp. 27-64, 1998.

[7] Pagano, M., and Roell, A., "The choice of stock ownership structure: Agency costs, monitoring, and the decision to go public", Quarterly Journal of Economics 113, pp. 187-225, 1998.

\section{Jaisik Gong}

[Regular member]

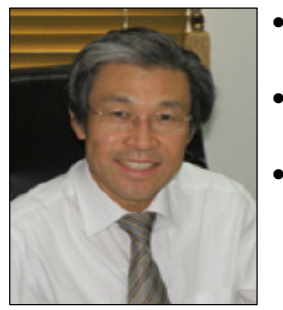

- Aug. 1984 : Seoul National Univ., MBA

- Aug. 1992 : Louisiana State Univ. (U.S.), Ph.D.

- Mar. $1995 \sim$ current : Daegu University, Dept. of Finance \& Insurance, Professor

\section{Choong-hwan Kim}

\section{[Regular member]}

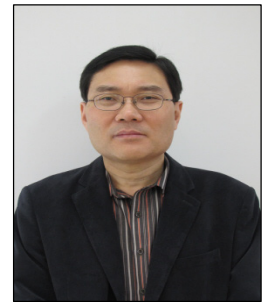

- Feb. 1983 : Sungkyunkwan Univ., BA

- Dec. 1995 : The Univ. of Texas at Austin (U.S.), Ph.D.

- Mar. $1996 \sim$ current : Kongju Nat'l University, Dept. of Industrial Information, Associate Professor

$<$ Research Interests $>$

Central Bank, Macroeconomics, Banking

$<$ Research Interests $>$

Corporate Finance, Banking 